\title{
Nile Green, The Love of Strangers
}

\author{
Sarita Olga Mizin \\ Lehigh University
}

Green, Nile. The Love of Strangers: What Six Muslims Learned in Jane Austen's England. Princeton, NJ: Princeton University Press, 2016. \$35. 416pp.

Nile Green's text, the product of nine years of careful research, cuts across the often rigidly perceived borders of Regency-era society, class, and nation by richly illustrating a network of charmingly quirky individuals. Working in the tradition of global historians like Antoinette Burton, Pankaj Mishra, and Anne McClintock, Green presents readers with a microhistory, tending to the details of dinner menus even as he looks at Jane Austen's England through a wide-angled lens. Readers should take Green's title at its word. Those looking for Jane Austen will be surprised to discover, instead, quite a bit of England, in all its religious, political, and international complexity. Readers searching for present-day caricatures of Islam in nineteenth-century dress will, likewise, be disappointed to find a legacy of friendship, diplomacy, and love.

Speaking against the expectations of anyone still clinging to the idea that Regency-era England was perfectly mannered and purely English, Green's text follows six young Persians from Tabriz to London, across the British Isle, and back again. Their aptly named chaperone, Captain D'Arcy, brings them to England from Iran at the behest of their crown prince 'Abbas Mirza. Offering Green an Austenian emplotment, the prince requests that these six students be educated in the ulum-i-jadid, or "new sciences" that were responsible for England's rapid development. Mirza Riza, Mirza Ja'Far, Muhammad 'Ali, Mirza Ja'far Husayni, and Mirza Salih would pursue subjects as diverse as artillery machining, chemistry, medicine, engineering, and language in the interests of their ruler. This princely imperative thus launches six taliban, students, into the history, and heart, of England.

Green's history proceeds anecdotally as it organizes around three broad themes: knowledge, faith, and friendship. Mirza Salih, the student tasked with learning English in the capacity of a future diplomat and translator, authors the diary which forms the structure of the text. Green takes illustration as his method, and fills in the portrait that Austen's novels and Salih's diary sketch with colorful descriptions of local characters. The first two chapters on "knowledge" detail the students' struggle with finding an affordable language teacher suitably versed in Persian. These chapters witness the students' movements between the London house of their increasingly reluctant chaperone, the East India Company college town of Croyden, the paper mill town of Hampton Gay, and the varsities of Oxford and Cambridge. The characters of these two chapters include orientalist Sir John Malcolm, an entertainingly named professor of oriental literature at Addiscombe's East India College, Mr. John Shakespear, and evangelizing mathematician, Dr. Olinthus Gregory. Learning along with the students', readers achieve their own education in the history of Asian languages at Oxford, the evolution of the evangelical movement across the British Empire, and the growth of professional and military colleges outside of the Oxford and Cambridge establishment.

Turning to the theme of "faith," Green traces the students' tour through the West Country, offering up Austen's reflections on Bath next to Salih's own description. After being entertained by the likes of Mrs. Hester Piozzi, whose guests often included Samuel Jonson and Oliver Goldsmith, the students set off to see the technology of silk mills in Gloucester and make the acquaintance of a "holy and ascetic" Methodist, Miss Bleechley, who walks them through the sites of an ongoing controversy between Anglican polemicists and the Sunday School Movement of local Unitarians. After some history and reflections on rising Evangelicalism at Oxrord and Cambridge, the texts brings the students back to London. Taking a detour to Hannah More's wooded abode, the celebrated author of 
Practical Piety, readers hear of the students' education in Paley and Natural Theology before Mirza Salih finds a suitable apprenticeship under master printer Richard Watts. Ironically, taliban Salih finds himself happily set-up in the imperial center of Christian missionizing, the printing shop of the Bible Society.

Green's final two chapters reinforce the argument of the text, mainly that a portrayal of the encounter between the "West" and "East" as entirely separate and inevitably combative requires a lot of historical subtraction and motivated amnesia. Taking "friendship" as its closing, these final anecdotes imagine the indulgences of Mirza Salih during students' trips to the theater and visits to their friends' dinner tables. Peeking into the intimacies of London's society both high and low, we are introduced to customs of etiquette, courtship, and gastronomy. Interestingly contrasted with Salih's experiences are the relationships of another student, Muhammad 'Ali, an apprentice in the machine shop of political radical Alex Galloway. Amity takes many valences in these final chapters in which diplomacy and dining are just a few. In a move worthy of an Austenian marriage plot, once achieving their educational objectives and hearing of their impending return to Iran, 'Ali marries an Englishwoman, the niece of his master, and brings her from the heart of Empire to the heart of Iran.

While Green resists the attempt to overemphasize the impact of the students' education back in Iran, he does offer a postscript to Salih's diary by noting the students' successful political and military careers. If readers are more interested in the details of Mirza Salih's diary than Jane Austen's England, Green offers up his Terrains of Exchange for further reading. In the end, some might say the repeated connections to Jane Austen are unnecessary or tedious. Such a critique would be missing the point. The Love of Strangers is really a history of Regency England, a patchwork of samples in quotidian life as seen and imagined through a Muslim gaze. By placing Salih and Austen's words and history side by side, Green identifies the places where Austen's novels left off entire swaths of England. Minding the gaps, Green places Salih's words into Austen's silences, and in merging the two describes a more varied portrait of an incompletely remembered England.

\section{Cite this Review}

https://doi.org/10.20415/rhiz/033.r04

RHIZOMES ISSN 1555-9998 ^ 230 East Hall Bowling Green State University Bowling Green, OH 43403

Editors: Ellen Berry and Carol Siegel. Reviews editor: Craig J. Saper. Technical editor: Helen J Burgess 